\title{
Internal mycoflora of Chinese straw mushroom basidiocarp-in vitro effects on mushroom growth'
}

\author{
Lydia I. Rivera-Vargas and Paul R. Hepperly ${ }^{2}$
}

\begin{abstract}
Twelve genera and species of fungi were identified from surface disin. fected $\left[0.5 \% \mathrm{Ca}(\mathrm{OCl})_{2}\right.$ for $4 \mathrm{~min}$.] mushroom pileus tissue. Overall fungi, Rhizopus sp. (30\%) and Monilia sitophila (asexual stage of Neurospora sitophila Shear ef Dodge) $(10 \%)$ were the most frequently recovered species. Aspergillus flavus Link ex Fries, A. fumigatus Fries., M. sitophila and Chaetomium bostrychodes Zopf were found both as internal fungi in the basidiocarps and competitors on sugarcane bagasse mushroom beds. Radial growth reduction of $V$. volvacea by fungal competitors depended on incubation temperature and the nature of the fungal competitor present. In vitro antagonism was tested for the Chinese straw mushroom and its internal basidiocarp mycoflora. Aspergillus niger van Tieghem caused $100 \%$ reduction of mushroom mycelial growth at $27^{\circ}$ and $35^{\circ} \mathrm{C}$, whereas A. carbonarius (Bainier) Thom caused $62.5 \%$ mushroom mycelial growth reduction at $27^{\circ} \mathrm{C}$, and $38.8 \%$ at $35^{\circ} \mathrm{C}$. Generally the internal mycoflora was less antagonistic at $35^{\circ} \mathrm{C}$ than at $27^{\circ} \mathrm{C}$.
\end{abstract}

\section{INTRODUCTION}

Volvariella volvacea (Bull ex Fries) Sing. is subject to a great number of diseases caused by fungal pathogens. These and other fungi also cause Chinese straw mushroom losses through competition. Chang (3) mentioned the bubbles caused by Mycogone sp., white plaster mold or flour mold by Scopulariopsis sp. and Verticillium sp. as major pathogens of V. volvacea.

Yee and Chang-Ho (13) observed that Aspergillus niger van Tieghem, A. fumigatus Fres. and Coprinus sp. were the first fungi that appeared growing on straw substrates. They studied in vitro effect of those fungi on $V$. volvacea mycelium. Aspergillus fumigatus and Coprinus cinereus [C. lagopus (Fr.) Fr.] reduced Chinese straw mushroom growth. ChangHo and Yee (6) compared the ability of $V$. volvacea and $C$. cinereus to compete for space and nutrients. These fungi share similar nutritional and environmental requirements. Besides these studies, little information is available on the diseases and pests on Chinese straw mushroom.

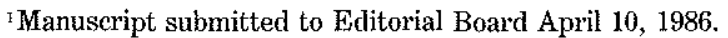

${ }^{2}$ Graduate Research Assistant; and former Associate Professor of Plant Pathology, Department of Crop Protection, College of Agricultural Sciences, University of Puerto Rico. Mayagüez, P. R. 00708. Second author is at present Research Plant Pathologist, USDA, Tropical Agriculture Research Station, Mayagüez, Puerto Rico 00708. 
In the common mushroom. Agaricus bisporus (Lange) Sing., Forer et al. (7) pointed out Verticillium malthosei, Mycogone perniciosa and Dactylium dendroides as frequent pathogens and Verticillizum sp. as the most important pathogen of all. It infects $A$. bisporus primordium and the pileus and the stipes of mature basidiocarps (12).

\section{MATERIALS AND METHODS}

Internal mycoflora related with mushroom basidiocarps

Fungi from internal portions of mushroom basidiocarps at the egg stage (the preferred stage for harvesting) were isolated and identified $(1,2,9,10)$. Direct isolates were made from pileus tissue. Pileus tissue (4 $\left.\mathrm{mm}^{2}\right)$ disinfected with aqueous solution of $\mathrm{Ca}(\mathrm{OCl})_{2}(0.5 \%)$ for 4 min were placed in 9-cm Petri dishes with potato dextrose agar (PDA). Four different treatments were used for the isolation test: PDA, acid PDA (APDA) with lactic acid, PDA with chloramphenicol $(100 \mathrm{p} / \mathrm{m})$ and APDA + PDA with chloramphenicol containing 5 pieces of pileus tissue per Petri dish. Ten replications of each treatment were done. The plates were incubated at $35^{\circ} \mathrm{C}$ for 4 days. Internal fungi were identified and frequency data was recorded.

Antagonism test between internal basidiocarp mycoflora and Chinese straw mushroom vegetative growth

The purpose of the antagonism test was to evaluate the interaction between internal mycoflora of the basidiocarp and the Chinese straw mushroom vegetative growth. The study was done with a modification of the dual culture technique described by Yee and Chang-Ho (13), which consists of two disks of pure culture $(4 \mathrm{~mm}$ diam.), one from a pure culture of Chinese straw mushroom and the other one from the internal basidiocarp species in a Petri dish with PDA with sugarcane bagasse. The disks were $4 \mathrm{~cm}$ apart. Colony diameters for each test fungus were recorded daily for 1 week.

\section{RESULTS AND DISCUSSION}

The following tabulation shows that bacterial contamination was reduced when chloramphenicol, lactic acid, or both were used.

\begin{tabular}{ccc} 
& \multicolumn{2}{c}{ Percent $^{3}$} \\
\cline { 2 - 2 } Medium & V. volvacea & Bacterial \\
recovered & contamination
\end{tabular}

Potato Dextrose Agar (PDA)

PDA + chloramphenicol $(100 \mathrm{p} / \mathrm{m})$

APDA $(\mathrm{pH}=5.4)$

APDA + chloramphenicol

$\begin{array}{rr}100 & 90 \\ 98 & 58 \\ 72 & 86 \\ 70 & 24\end{array}$

${ }^{3}$ Based on 50 isolations from random pileus fragments. 
Clean cultures were best obtained from the egg and button stages by isolating from the stipe rather than from the pileus as is recommended in most references (4). Acid media and chloramphenicol reduced bacterial contamination by $4 \%$ and by about $35 \%$, respectively. The combination of these two additives reduced bacterial contamination by more than $65 \%$, showing the synergism of the two practices.

The following tabulation shows the twelve species of fungi identified from surface disinfected mushroom pileus tissue and their frequencies.

Fungi

Frequency $(\%)^{4}$

1. Aspergillus carbonarius (Bainier) Thom

2. A. flavus Link ex. Fries

2

2

3. A. fumigatus Fries

4. A. niger van Tieghem

4

5. Cladosporium sp.

6. Curvularia senegalensis (Spig.) Subram

7. Chaetomium bostrychodes Zopf

8. Monilia sitophila, asexual stage of Neurospora sitophila Shear et Dodge

9. Paecilomyces variotii Bainier

10. Penicillium nigricans Bainier ex Thom $=$ P. janczewskii Zaleski

11. Pestalosphaeria elaeidis (C. Booth + Robertson Van der Aa

12. Rhizopus sp.

${ }^{4}$ Based on 50 random pileus fragments plated on acid potato dextrose agar ( $\mathrm{pH} 5.4$ ).

Overall fungi, Rhizopus sp. (30\%) and $M$. sitophila (10\%) were the most frequently recovered species. These are sugar fungi according to ecological grouping (5). Aspergillus flanus, A. fumigatus, M. sitophila and Chaetomium bostrychodes were found growing on sugarcane bagasse mushrooms. A. flavus was found growing on early stages of mushrooms basidiocarp. Isolates of this fungus can be potent mycotoxin producers, which would be a hazard to human and animal health (8). Their role as a health hazard in mushrooms deserves further investigation.

Most of the fungi isolated from mushroom basidiocarps were imperfect fungi with ascomycete affinities. Most are sugar fungi. Basidiomycetes, ascomycetes and imperfect fungi with Ascomycete affinities were present in the Chinese straw mushroom beds, where basidiomycete thermotolerant cellulose decomposers appeared most prominent (11).

Radial growth reduction of $V$. volvacea by fungal competitors depends on incubation temperature and the nature of the competitor present (fig. 
$1 \mathrm{a}, \mathrm{b})$. Antagonism in vitro test done with the mycoflora isolate from mature basidiocarps showed that Aspergillus niger caused $100 \%$ mushroom mycelial growth reduction at $27^{\circ}$ and $35^{\circ} \mathrm{C}$, whereas $A$. carbonarius caused $62.5 \%$ mycelial growth reduction at $27^{\circ}$ and $38.8^{\circ} \%$ at $35^{\circ} \mathrm{C}$. Most of the competitors were less antagonistic at $35^{\circ} \mathrm{C}$ than at $27^{\circ} \mathrm{C}$. Thirty-five degrees Celsius is near the termperature of optimal vegetative growth for Chinese straw mushrooms.

Internal infection of mushroom basidiocarps was common. The effect of these infections could be negative considering their antagonism to mushroom growth in vitro and the presence of possible toxigenic isolates. Future studies should focus on determining when infection takes place and its practical significance in the production and use of mushrooms.

\section{RESUMEN}

Micoflora interna de los del basidiocarpos de la seta china y su efecto sobre el crecimiento del hongo

Se identificaron especies de hongos aisiados del basidiocarpo de la seta china, Volvariella volvacea (Bull ex Fries) Sing; las más frecuentes fueron Rhizopus sp. (30\%) y Monilia sitophila (erapa asexual de Neurospora sitophila Shear et Dodge), con 10\%. De las especies encontradas Aspergil-
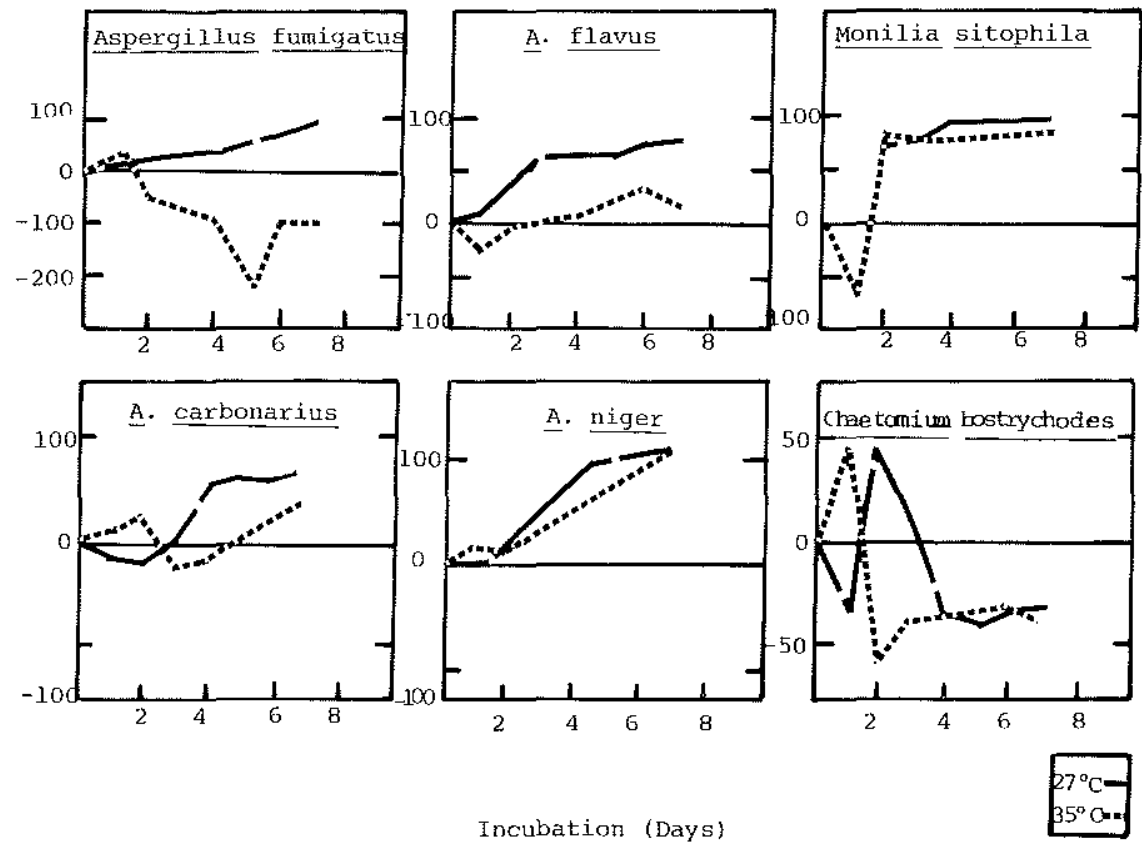

FIG. 1 A.-Radial growth reduction (\%) of $V$. volvacea mycelium by internal fungi isolates from mature basidiocarps at $27^{\circ}$ and $35^{\circ} \mathrm{C}$. 

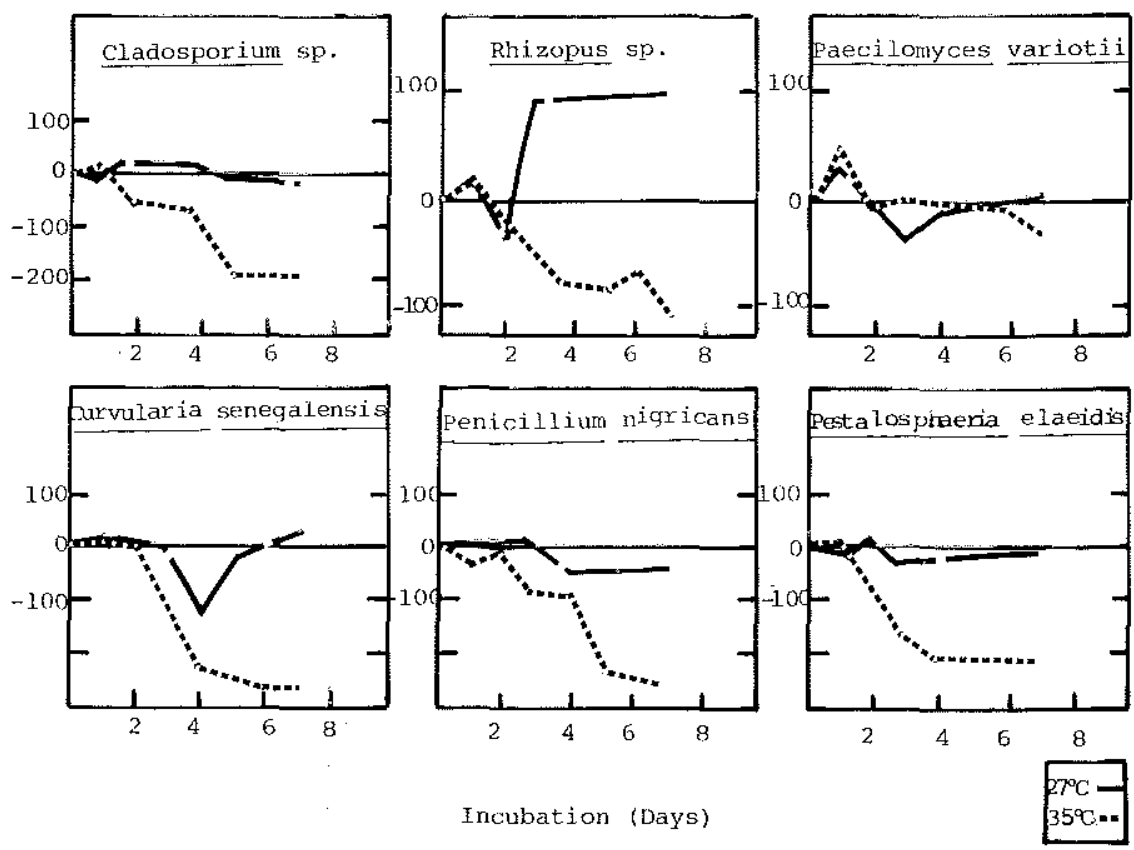

FIG. 1 B,-Radial growth reduction (\%) of $V$. volvacea mycelium caused by internal fungi isolates from mature basidiocarps at $27^{\circ}$ and $35^{\circ} \mathrm{C}$.

lus flavus Link ex Fries, A. fumigatus Fries., M. sitophila y Chaetomium bostrychocies Zopf aparecieron ereciendo dentro del basidiocarpo de la seta y sobre la cama de bagazo de caña de azúcar.

La reducción del crecimiento radial de $V$. volvacea por hongos competidores depencie de la temperatura de incubación y la naturaleza del hongo competidior presente. Las pruebas de antagonismo realizadas con $V$. volvacea y la micofiora aisiada de los basidiocarpos maduros demostraron que Aspergillus niger van Tieghem causa un $100 \%$ de reducción en el crecimiento micelial de la seta a $27^{\circ}$ y $35^{\circ} \mathrm{C}$, mientras que $A$. carbonarius (Bainier) Thom causa una reducción de crecimiento miceliar de $62.5 \%$ a $27^{\circ}$ y $38.8 \%$ a $35^{\circ}$; la mayoría de los competidores son menos antagónicos a $35^{\circ} \mathrm{C}$ que a $27^{\circ} \mathrm{C}$.

\section{LITERATURE CITED}

1. Ames, L. M., 1963. A monograph of the Chaetomiaceae. U.S. Army Res. Devel. Ser. $2^{\circ}$, Reprint Cramer, Lebre.

2. Barnett, H. L. and B. B. Hunter, 1972. Illustrated Genera of Imperfect Fungi. 3rd. ed., Burgess Publishing Co., Minneapolis, Minnesota.

3. Chang, S. T., 1978. Volvariella volvacea pp. 573-601. In: The Biology and Cultivation of Edible Fungi, S. T. Chang and W. A. Hayes, Eds, New York and Isondon, Academic Press.

4. — , 1982. Mushroom Spawn. pp. 36-37. In: The Biology and Cultivation of Edible Fungi, S. T. Chang and W. A. Hayes, Eds, New York and London, Academic Press. 
5. —_, 1982. Ecological studies of Volvariella volvacea pp. 187-197. In: Tropical Mushrooms: Biological Nature and Cultivation Methods. S. T. Chang and J. H. Quimio, Eds, The Chinese University Press, Hong Kong.

6. Chang-Ho, Y. and N. T. Yee, 1977. Comparative study of the physiology of Volvariella volvaced and Coprimus cinereus. Trans. Br. Mycol. Soc. 68 (1): 167-72.

7. Forer, L. B., P. J. Wuest and V. R. Wagner, 1974. Occurrence and Economic Impact of Fungal Diseases of Mushrooms in Pennsylvania, Plant Dis. Rept. 58: 987-91.

8. Neergard, P., 1977. Impact of Seed-borne and Storage Fungi on Animal and Human Health pp. 298-307. In: Seed Pathology. Vol.I. The MacMillan Press. L.T.D. London and Basingstoke.

9. Raper, K. I. and D. I. Funnell, 1985. The Genus Aspergillus. Williams and Willins Co. Baltimore.

10. Raper, K. B. and C. Thom, 1949. A manual of Penicillia, pp. 122-25. Williams and Wilkins Co., Baltimore, Md.

11. Rivera-Vargas, L. and P. R. Hepperly, 1985. Assessment of Chinese Straw Mushroom (Volvariella volvacea) Fungal Competitors on Sugarcane Bagasse. (In Review).

12. Wuest, P. J., 1983. Resources Needed to Farm the Champignon. Mycologia 85 (2): 341-50.

13. Yee, N. J. and Y. Chang-Ho, 1980. Interaction Between Volvariella volvacea and Some Weed Fungi. Trans. Br. Mycol. Soc. 75 (3): 498-501. 